\title{
Zakopane, Poland: The Critical Analysis of Contemporary Large-Scale Architecture
}

\author{
By Ewa Stachura* \& Marta Mantyka
}

\begin{abstract}
Zakopane is a Polish winter resort renowned for its vernacular, wooden architecture and strong regional culture. Development of the city is linked strongly to tourism and nestled in the foothills of the Tatra Mountains, Zakopane and the Podhale region since the second half of the $19^{\text {th }}$ century has attracted mountaineers, researchers, scientists and later sanatoriums for tuberculosis patients. The city obtained charter rights in 1933. Subsequent development has seen a progressive change in the local architectural style with the construction of larger scale buildings to accommodate growing visitor numbers. Currently, Zakopane attracts around 3.5 million tourists annually making it one of the most visited cities in Poland. Specific changes to the built form are the result of newly constructed buildings predominately designed for wealthy, out of town people as investments in rental and time-share vacation accommodation bringing inappropriate adaptations of the local, vernacular architecture such as unauthentic decorative motives and citations. Nevertheless, while most properties offer high quality, luxury accommodation with many amenities it has made real estate prices unobtainable for local residents and changed the socioeconomic and urban aspects of everyday life in Zakopane. This paper aims to study and classify new, large-scale investment in the city such as hotels, condo hotels and apartment buildings and their influence on the vernacular urban architecture of the city. It will also investigate and characterise various qualities of these new developments such as functionality, aesthetics and the protection of existing cultural values such as the city centre and area around the Ski Jump.
\end{abstract}

\section{Introduction}

The popularity of Zakopane has been increasingly growing since the middle of $19^{\text {th }}$ century Starting then Zakopane was primarily a lodging and a ski centre. ${ }^{1}$ Currently, the most popular place for skiing is nearby Bialka Tarzanska, and, in the past 30 years, Zakopane has transformed into a more significant urban centre offering lodging as well as shopping.

This change and the growing popularity of this touristic destination in Poland and abroad have altered the urban layout. The city today is over-developed, and lot prices have gone up impacting the investors' decisions on the size of new buildings in the town. Also, to meet the needs of demanding clients, the accommodation must offer more amenities, requiring more space. This paper aims

\footnotetext{
*Associate Professor, Institute of Architecture, State University of Applied Sciences in Raciborz, Poland.

"University of Hertfordshire, UK.

1. W. Białas, "Budarka," in Zakopane czterysta lat dziejów I (Krakow, Poland: Krajowa Agencja Wydawnicza, 1991).
} 
to scrutinise and classify new large-scale investment in the city like condo hotels, hotels and apartment buildings and its influence on the urban design of the town. It will also investigate and characterise various qualities of this new development like functionality, aesthetics and will attempt to evaluate its impact on existing cultural/heritage values by the example of the city centre and an area around the Ski Jump.

\section{Literature Review}

Zakopane, its history, architecture and original regional culture have been attracting researchers since the mid-nineteenth century. Many valuable, interdisciplinary studies developed at the turn of the century when the Polish national style was shaped, taking the form of the Zakopane style. ${ }^{2}$ Its creator, Stanisław Ignacy Witkiewicz, published many articles, books, architectural designs and drawings. Because for decades Zakopane continuously held the function of an important artistic centre in Poland, the artists effectively supported the protection of the local building tradition. The value of Zakopane's heritage increased in times after WWII: Zakopane - unlike most cities and towns, it was not destroyed. The eclectic currents returning in waves often referred to the forms of the Zakopane Style, triggering discussions and disputes. Nowadays, in the subject literature, the architectural form of objects erected in Zakopane and the vicinity of postmodernism is analysed.

\section{The History and Contemporary Development of Zakopane}

$$
\text { Zakopane - The History }
$$

Zakopane is a very well-known touristic destination in Poland, currently inhabited by approximately 27,000 residents. Its' popularity is still growing, and now, Zakopane is the second most popular city in the Lesser Poland Voivodeship, and the 6th most popular vacation destination in Poland. Year after year it attracts a larger group of visitors.

Zakopane is situated in the Podhale region, directly at the foot of the Tatra mountains, the highest range of the Carpathian Mountains. This geographic placement was the main reason why Zakopane was settled quite late in comparison to the neighbouring villages (first mentioned as Nowa Osada in 1624 .) ${ }^{3}$ It was due to a problematic, Alpine climate of the place, the lack of good, fertile soil and the incline of the hills were negatively impacting the agriculture. Until the discovery of various metals in the Tatras, the primary purpose of the settlement was sheep

\footnotetext{
2003).

2. Z. Moździerz, Geneza i Rozwój Stylu (Zakopane, Poland: Wydawnictwo Tatrzańskie,

3. M. Mantyka, "Zanim Powstało Miasto," in Zakopane 75 lat Praw Miejskich (Zakopane, Poland: Urząd Miasta Zakopane, 2008).
} 
herding. ${ }^{4}$ In 1766 a forge was built in Kuźnice, doing the split between the village and the workplace. The route between both places has, later on, became the most popular and prestigious street in the Zakopane, Krupowki. During the romanticism, the mountain landscape has become increasingly popular, and for the rather poor village of Zakopane, it meant first tourists and the impulse to grow. Visitors were coming to appreciate the mountains, and to treat various pulmonological disorders. In 1818 the village was populated by 1805 people. The First Partition of Poland saw the whole Zakopane region fall under the Austrian rule. The mountain area was administrated directly by the State. Property ownership of Kuźnice and the forge, as well as the surrounding, was sold, the family of Jan Vincent Homolacs became the owners of Zakopane for 50 years. Later, it was owned by Ludwik Eichborn (1869-1879), Magnus Pelz (1879-1888), and Jakub Goldfinger (1889). Count Władysław Zamoyski (Paryski and Paryska 1995), who acquired Zakopane estate in May 1889 turned out to be the most prominent owner of this area. Nevertheless, and he turned it over to the Nation in 1924.

The first wooden church was built in 1847 and the first parish priest, Józef Stolarczyk, came to Zakopane. His presence was significant for the further development of the settlement regarding village planning and the foundation of the first public institutions. Zakopane hosted a growing number of scientists and tourists from the neighbouring countries, yet the conditions were severe due to food shortages, low standards of lodging and a lack of proper roads. The primary source of income for the locals was still cattle and sheep farming.

Many organisations and societies came into existence to help the development of the town and the area. The most important was the Towarzystwo Tatrzanskie (Tatra Society) that marked out many mountain routes and built mountain lodges, including the Morskie Oko mountain hostel established in 1874. The wooden building of the Dworzec Tatrzanski - a concert hall with the first library and reading room started its activity in 1882 . The Society donated money for the formation and running of the Woodcarving School and promoted Zakopane culture with various publications. Doctor Tytus Chałubiński raised the popularity of Zakopane (Długołęcka and Pinkwart 1989) by promoting the benefits of the Podhale region climate as fighting Tuberculosis. Following these climate properties, in 1885, Zakopane got officially recognised as a health resort and a year after, the first hospital in the Town was opened. ${ }^{5}$ Growing population and the number of tourists brought the need for modern infrastructure.

Poland at the turn of XIX and XX century was partitioned among three foreign powers. As a counteraction, the idea of national revival occurred and attracted many writers, scientists, artists, painters, composers, conspirators, naturalists and explorers. Zakopane with its traditional culture and indigenous architecture became the important place and the idea of the national style. Styl Zakopiański (Zakopane style) in architecture created by Stanisław Witkiewicz was

\footnotetext{
2003).

4. Mantyka and S. Momot, Zakopane i Tatry (Zakopane, Poland: Wydawnictwo Krokus,

5. Moździerz and R. Marcinek, Rys Historyczny Rozwoju Przestrzennego i Architektonicznego (Zakopane - Kraków, Poland, 2016).
} 
strongly inspired by the vernacular style of the local Highlanders. It also relates to other forms of design, e.g. furniture design, art, and crafts.

Zakopane received the city status in October 1933 what stimulated the city's urban development and to established Zakopane's position as a tourist centre by the construction of a ski jump and cable car to the top of Kasprowy Wierch as well as Gubalowka funicular.World War II saw Zakopane taken over by Germans and turned into a recreation centre with a large hospital for German soldiers. It also became a key location for illegal routes for underground organisations to keep the communication between Poland and its' government in Great Britain. After the war Zakopane resumed its role of a health resort, gradually moving towards tourism and a sporting centre. The growing number of tourists brought many new hotels and accommodation facilities.

\section{The Urban Development of Zakopane}

Zakopane has developed in rather hostile natural conditions - located at the foot of the Tatra Mountains and therefore faces the capricious climate, long and harsh winters, short summers.

In the XVI century was used by the shepherds during the summertime, the constructions were wooden and provisional, gradually moving towards more meticulous, permanent interlocking log cabins between XVII century to the middle of XVII century. ${ }^{6}$

The climate forced the local people to adopt the vernacular architecture to the surrounding conditions. The openings, like doors and windows, were tiny and placed on the south side of the buildings. The over- hanged roofs, unlike buildings in the Alps were much steeper, in between 48-53 degrees, to help to remove the snow and withstand the local wind, Halny. The sheds placed on the west side protected households from the reoccurring southwest winds (Figure 1). A typical floor plan was rather simple, founded on a rectangular shape with an entrance hall and two rooms: "a black" chamber heated with an open fire, wood-burning stove for everyday use, and "a white" one, representational, for the distinctive guests. The endemic style of vernacular architecture appeared both in Zakopane and the surrounding area of Podhale. ${ }^{7}$

The development of Zakopane as a summer destination and a spa town pushed the Highlanders to increase the size of the newly constructed houses, now having often even four rooms and a porch. ${ }^{8}$ The guests were also accommodated under the roof, in the attic.

Later, after the discovery of Zakopane by Tytus Chałubiński 4 room house was no longer sufficient to accommodate vacationers, and the eclectic style, called "the Swiss style" was introduced to Zakopane. The Swiss style overtook the

6. S. Żychoń, "Rozwój Przestrzenny i Budownictwo,” in Zakopane czterysta lat dziejów I (Krakow, Poland: Krajowa Agencja Wydawnicza, 1991).

7. W. Matlakowski, Budownictwo ludowe na Podhalu (Akademia Umiejętności; Skład główny w Księgarni Spółki Wydawniczej Polskiej, 1892).

8. W. Eljasz, Ilustrowany przewodnik do Tatr, Pienin i Szczawnic (Poznan, Poland: J. K. Żupański, 1970). 
village and was present until the end of XIX c. To this day on, the Swiss style buildings from that era are a vital part of the local landscape. The local architecture style adapted some elements of the Swiss style. ${ }^{9}$

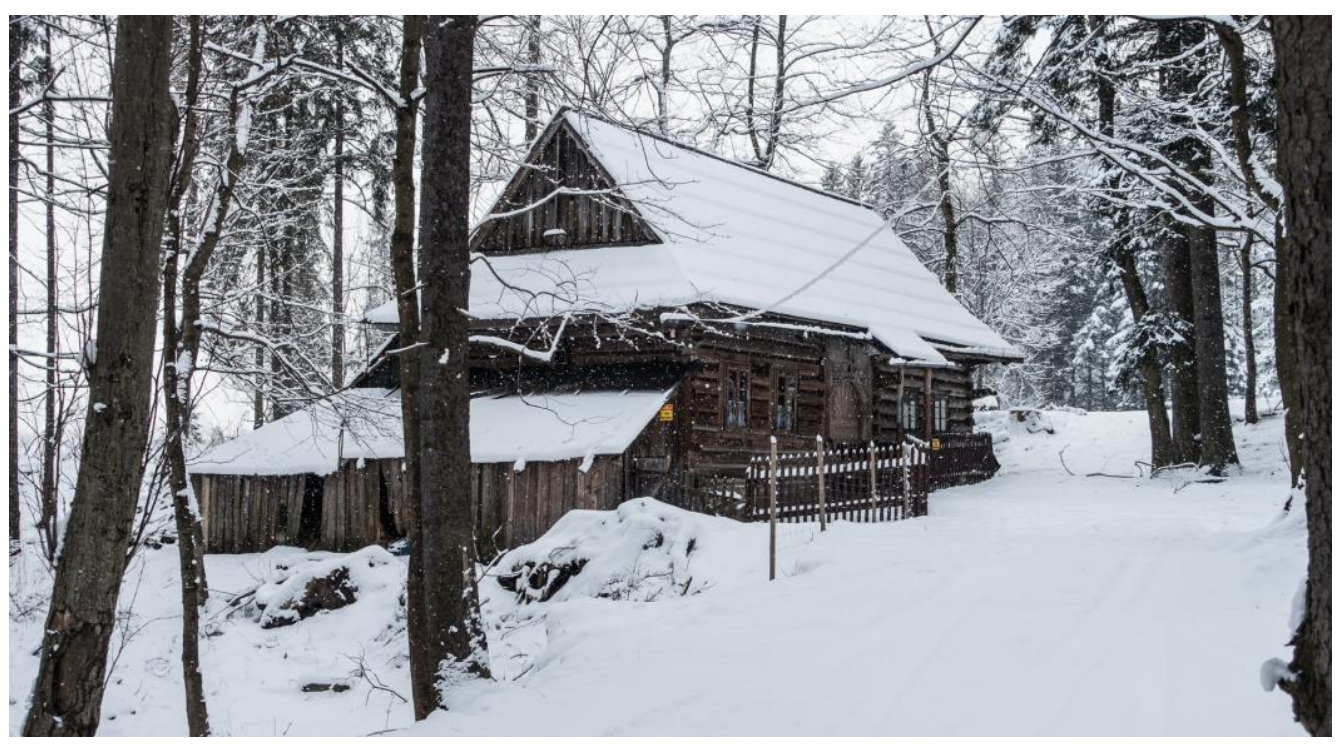

Figure 1. The Oldest Wooden House in Zakopane

Source: Author's Archive.

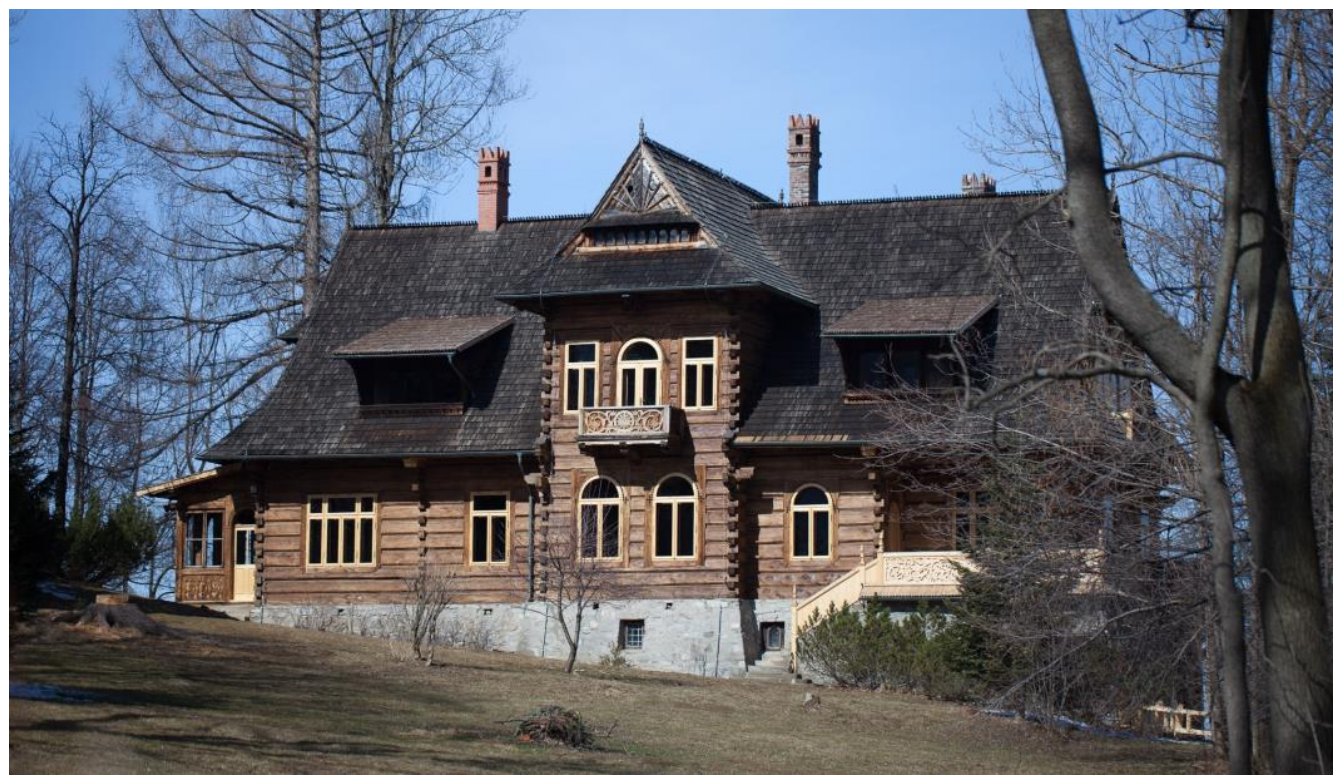

Figure 2. Willa Pod Jedlami by Stanislaw Witkiewicz

Source: Author's Archive.

9. J. Tarnowski, "Styl Alpejski w Środkowej Europie i Polska Kontrakcja wobec niego Styl Zakopiański,” Estetyka i Krytyka 2, no. 25 (2012): 232-246. 
A big supporter of the local vernacular style was artist Stanisław Witkiewicz whose idea was to create a national style not only for architecture but also for the other forms of artistic expression. ${ }^{10}$

The first building designed by Witkiewicz in style known as Styl Zakopianski (Zakopane Style) was Villa Koliba (Completed in 1892 at Kościeliska Street). It is form, structure, and used materials were inspired by a typical Highlander house but with many eclectic citations. ${ }^{11}$ Buildings were much bigger, comparable to standard two-storey Swiss style villas. This first design was very successful and followed by other projects. Later on, Witkiewicz was attaching more vernacular style elements in his projects like stone wall base, multiple roof ridge, decorative pins and the crossbeam. The most famous buildings by Witkiewicz are Willa pod Jedlami (The House under the Firms, 1897; Figure 2) ${ }^{12}$ and the Chapel of the Sacred Heart in Jaszczurówka. ${ }^{13}$

The train system completed by 1899 connected Krakow and Zakopane caused the development of the lodging base and helped the transportation of heavy building materials like bricks and other fireproof materials. So, more stone buildings appeared in the cityscape at the turn of XIX and XX centuries. Nevertheless, the transition of Zakopane style to use brick by Stanisław Witkiewicz was unsuccessful, what the building of Muzeum Tatrzańskie (19131922) shows. Unsuccessful attempts are still present in the cityscape.

The first modernist buildings appeared in Zakopane between 1910-1911. At that time the village was developing quickly and started to resemble the city structure. The sewage and water systems were modernized.

During WW II, under the German siege, Zakopane was under order action Ordnungsaktion. The law prohibited constructing new buildings, and only a few buildings were erected during the war. The architectural style during the war was a compromise between regional and modern, and it became an essential inspiration in shaping the New Zakopane style. After the war, high levels of wood and stone crafts and social realist forms, which continued throughout the interwar period, characterised the architecture. Some mountain hostels and the "Dom Turysty" are the examples of buildings of the mentioned above "New Zakopane Style". Along with Poland's political changes in the early 1990s, mail pedestrian track Krupówki was modernised. The tilted lampposts, for example, were highly controversial being described as chaotic and disharmonic.

10. T. Jabłońska, Styl Zakopiański Stanisława Witkiewicza (Poland: Olszanica BOSZ Publisher, 2008).

11. S. Krzysztofiak-Kozakowska, Sztuka Młodej Polski (Kraków, Poland: Ryszard Kluszczyński Publisher, 1999).

12. Moździerz "Dom pod Jedlami Pawlikowskich," in Wydawnictwo Muzeum Tatrzańskiego im. Dra Tytusa Chatubińskiego w Zakopanem No. 24 (Zakopane, Poland, 2003).

13. J. W. Rączka, Walka o Polski Styl Narodowy w Architekturze (Krakow, Poland: Wydawnictwo Politechniki Krakowskiej, 2001). 


\section{The Large-Scale Buildings in the Contemporary Zakopane}

Throughout the history of the city, Krupowki Street was always one of the most important parts of the settlement. ${ }^{14}$ Nowadays the popularity of this place precedes the attractiveness of the surrounding Tatra Mountains, and the tourists are more likely to visit the street, rather than go hiking. Zakopane has become the allyear-round destination for tourists, as it is one of the most popular streets in Poland among Krakowskie Przedmieście in Warsaw, Floriańska in Kraków, Bohaterów Monte Cassino in Sopot, and Piotrkowska in Łódź (turystyka.wp.pl 2014). For 20 years the main change associated with tourism in the city is the fact that previously people came for longer periods, but only during the summer or winter school holidays. Currently, Zakopane is equally as popular in the fall and spring, but more as a weekend destination.

These factors are the main reason why the town is booming, and therefore is an attractive real estate investment option for well-to-do people from outside the city.

The most popular is the purchase of an apartment or a condominium. The potential owner can either use it himself/herself or for short-term rental. Many companies are offering the find and manage to book, as well as cleaning and maintenance services. The owner can use the place for around two weeks a year.

Lately, more attractive is the purchase of a room in a condo hotel- which is more expensive in comparison to the apartment, but it promises better investment returns (in some cases advertised as up to 50\%) and offers a broader variety of facilities- like swimming pools, spa, ski equipment rentals, restaurant, gym, 24 reception among others. The circumstances mentioned above attract wealthy investors who are willing to pay higher figures.

The prices of the real estate in Zakopane and Podhale region are comparable with the prices from a bigger city like, for example, Warsaw. Unfortunately, the average wages in the city are much lower, making it difficult to purchase an apartment for an inhabitant. The local people are often forced to move out, e.g. to Nowy Targ (the closest town of Zakopane), where apartment prices are still affordable, creating at the same time morning and afternoon commute traffic. In the future, it may also cause the problems of depopulation and gentrification.

Zakopane is a Polish winter resort renowned for its vernacular, wooden architecture and influential regional culture. Development of the city is linked strongly to tourism and nestled in the foothills of the Tatra Mountains. As mentioned before, Zakopane and after, whole Podhale region have attracted mountaineers, researchers, scientists and later sanatoriums for tuberculosis patients since the second half of the $19^{\text {th }}$ century. The city obtained charter rights in 1933 . Subsequent development has seen a progressive change in the local architectural style with the construction of more significant scale buildings to accommodate growing visitor numbers. Currently, Zakopane attracts around 3.5 million tourists annually making it one of the most visited cities in Poland. Specific changes to the

14. L. Długołęcka and M. Pinkwart, Zakopane Przewodnik Historyczny (Warsaw, Poland: Wydawnictwo PPTK Kraj, 1989). 
built form are the result of newly constructed buildings predominately designed for wealthy, out of town people as investments in rental and time-share vacation accommodation bringing inappropriate adaptations of the local, vernacular architecture such as unauthentic decorative motives and citations.

Nevertheless, while most properties offer high quality, luxury accommodation with many amenities, it has made real estate prices unobtainable for residents and changed the socioeconomic and urban aspects of everyday life in Zakopane.

This paper aims to study and classify new, large-scale investment in the city such as hotels, condo hotels and apartment buildings and their influence on the vernacular urban architecture of the town. ${ }^{15}$ It will also investigate and characterise various qualities of these new developments such as functionality, aesthetics and the protection of existing cultural values such as the city centre and area around the Ski Jump.

Communicationally, Zakopane does not have many roads. Many of those are unusually narrow or under a very steep incline. The condensed unique development does not allow significant changes in the existing transportation system. With an increased number of tourists visiting every weekend the amount of traffic is going up, making the driving around the city nearly impossible. On some occasions, for example, after the New Year's Eve 2018/19 the $22 \mathrm{~km}$ drive between Nowy Targ and Zakopane took up to 5 hours. Similarly, Zakopane does not have enough parking spaces. The areas around the city centre offer a couple of options to park, but it is not enough.

The underground car parks do not exist, and the negative occurrence is turning the green fields into the parking, destroying nature, and also the landscape of the city. Negative consequences of congestion affect the area of Kuźnice, which does not allow the drive-in entry, turning the surrounding Słowackiego and Mieczyslawa Karłowicza streets into the parking lot.

Common in Zakopane is car parking on sidewalks. The city authorities installed the parking poles to stop the cars from entering paths. It does regulate the situation in the summer, but during the winter, it prevents proper snow removal and therefore cases even more traffic.

The other consequence of city development is air pollution. It is caused both by car traffic and coal-based heating. The amount of particle pollution is exceeded even up to 100 days a year, and currently, Zakopane, based on the judicial decision from 2018 cannot charge the tourists the climatic tax. Also, in the times of the high season, the water supply system is not enough to provide the water to all of the households.

The local Masterplan from 1994 expired in 2003. Before the city's government was able to pass a new bill, building permits for around 10 years have been based on a case by case scenario, which has led to architectural chaos in the form of high-density and often inappropriate development, the disappearance of the green spaces, the oversizing of buildings and the lack of proper, regional policy objectives. It has a negative impact on this day, as it increased the overall size of

15. J. Pallasmaa, "Tradition and Modernity: The Feasibility of Regional Architecture in PostModern Society," The Architectural Review 183 (1988): 28. 
the buildings, and change the ratio between the building and green space. One of the biggest scaled construction in Zakopane is the Radisson hotel (Figure 3 and Figure 6, photos 1-2), on Bulwary Słowackiego street is the example of the out-ofscale development, that does not correspond well with the neighbouring architecture. Also, the construction of this format, on a small and narrow street, will cause communication problems. The other issues that are highly probable are noise, and lack of parking for inhabitants or churchgoers.

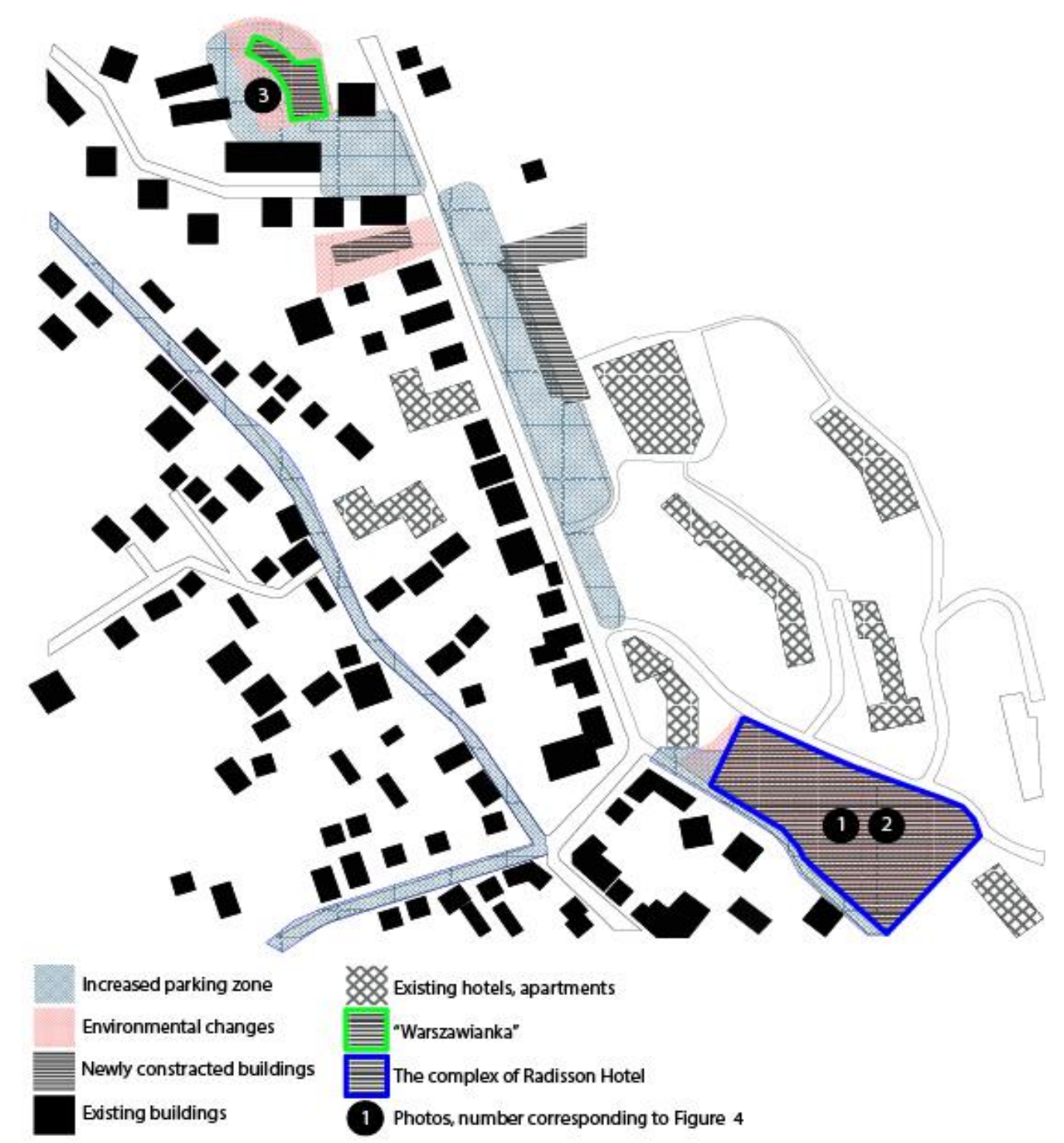

Figure 3. Map of the New Developments in Bulwary Stowackiego (Radisson Hotel) and Jagielońska Street (Warszawianka)

Source: Own Study.

The design of the three building refers to the Highlander style - the roofs are tilted; the façades resemble interlocking log cabin and wood. It does lack the authenticity of the vernacular architecture and feels like an unsuccessful imitation. 
Similarly, to the above mention, Goszczyńskiego street (Figure 4 and Figure 6 , photos 4-5), is a one-way street grovel three new condominium buildings will impact road. It used to be a green field, but due to the popularity of the area (the proximity to both ski jump and the city centre), it was developed. The biggest building is offering 90 new apartments, with a spa and an outside whirlpool.

Like at Bulwary Słowackiego, there are not enough parking spaces for the visitors, and the road is too narrow for such a massive scale development. The design of the complex is modern and aesthetically pleasing; yet again it contrasts with the single-family houses predominantly existing in this tranquil area.

Due to the shortage of plots, the new buildings are replacing old houses intended to be demolished. Therefore the costs of the property are usually very high, and a client demands the biggest buildings allowed by a local bylaw. In many cases the parking lot is underground, but no visitor or employee spaces are provided. Also, many buildings have virtually no green space, not to mention a lack of trees.

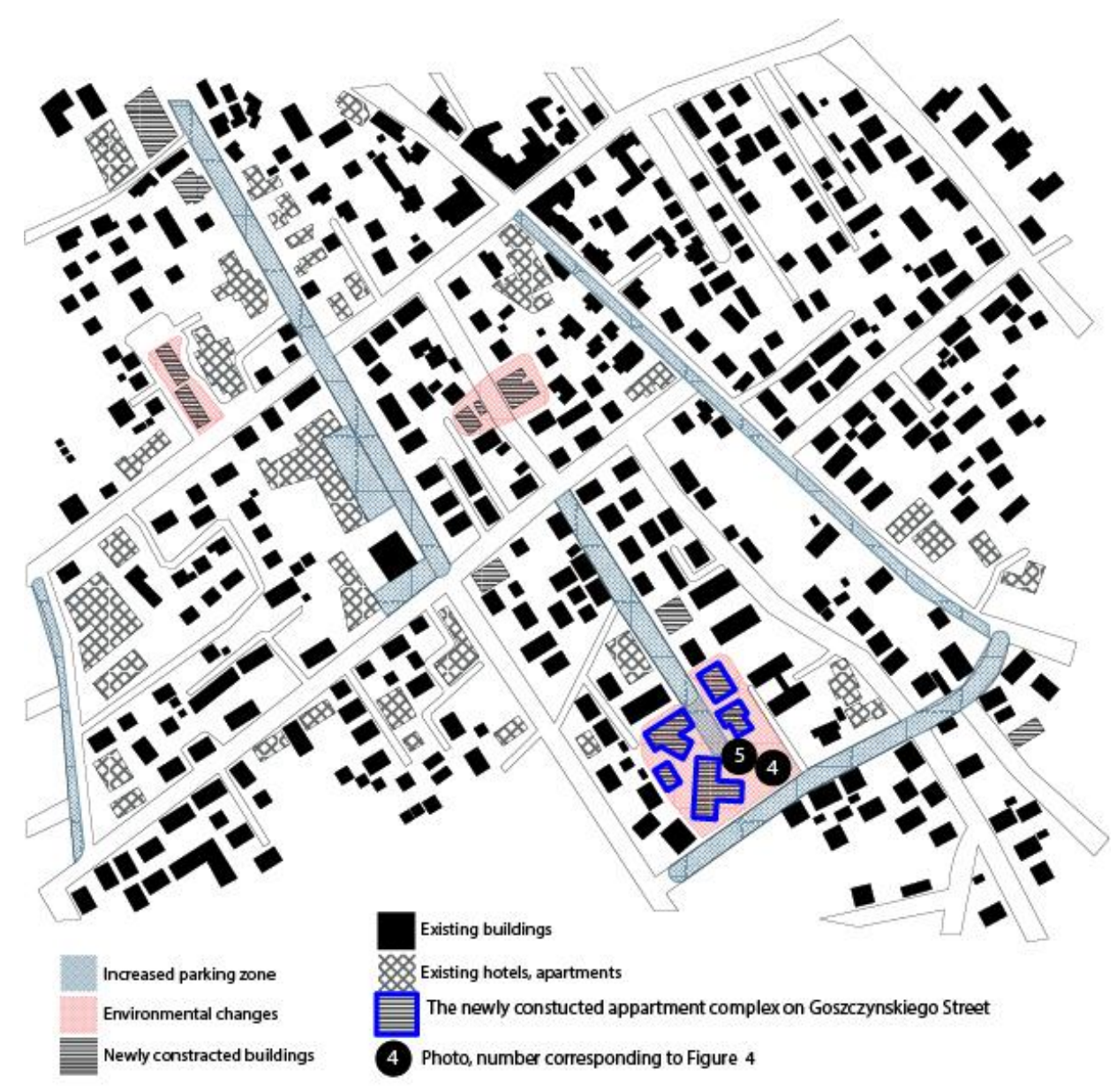

Figure 4. Map of the New Developments in Goszczyńskiego Street Source: Own Study.

The demolishing of the old buildings is questionable, as in some it causes the illegal scheme of burning down structures to sell or build. The contemporary 
architecture of Zakopane is problematic. In the past, decorative elements have been sparsely used by the locals, but currently, the architects opted for the designs that employ vibrant motifs used purely for decoration without the previous functional component. Also, the used patterns are often foreign, cartoonish and extensive. The transformation of other styles into the regional architecture is highly disputable and out of place, and quite often Zakopane is criticised for its' architecture.

The example would be a historical building of "Warszawianka" (Figure 3 and Figure 6, photo 3), at Jagielońska Street that due to the bad technical condition was demolished and in recent development got a half-arch arcade, called by the national press "Zakopane's Coliseum". Also, this building contains traditional elements which feel foreign.

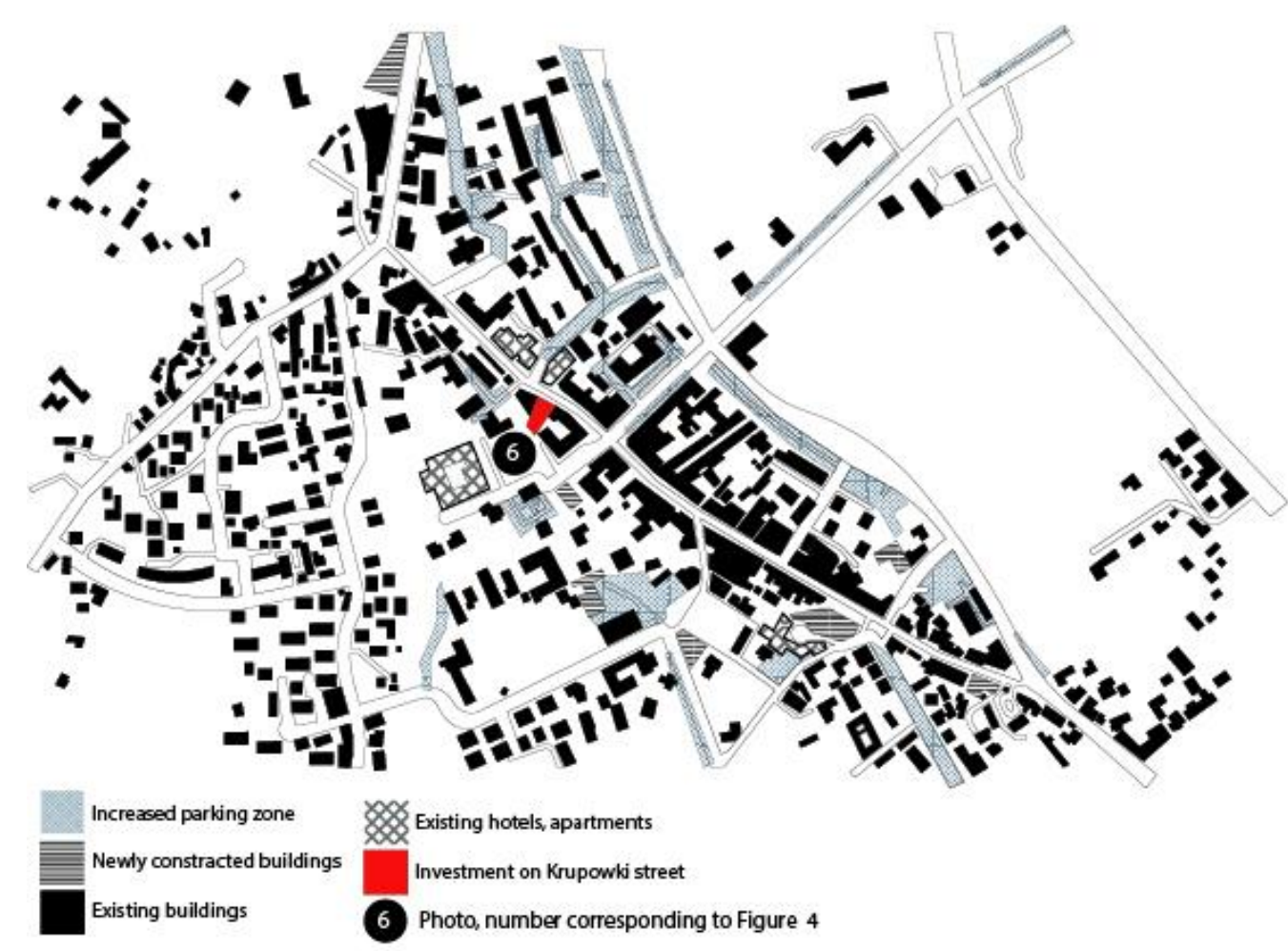

Figure 5. Map of the New Developments in Krupówki Street Source: Own Study.

The recent large-scale development in the main street (Figure 5 and Figure 6, photo 6) is a shopping and tourist apartment building. Because Krupowki is a predominantly pedestrian street, there is no access to the lot with a car. The closest parking space in Zborowskiego Street is rather small and insufficient, making it nearly impossible to provide the desired park car to serve this investment. Also, in comparison to other buildings in this location, the building seems out of scale and does not have the features of existing, historical architecture arrangement like the inside court, surrounded by the buildings. 
Vol. 6, No. $1 \quad$ Stachura \& Mantyka: Zakopane, Poland: The Critical Analysis of...

The examples cited do not exhaust all problems related to new buildings erected in Zakopane. Buildings of smaller scale (e.g. detached houses) often interpret traditional forms and details in a free manner. They lose their original function, size and often use an entirely different material than the native ones. Wealthy investors complicate the architectural form wanting to stand out from the surrounding buildings. These destructive patterns reproduced in many versions make it difficult to educate and popularize valuable vernacular architecture.

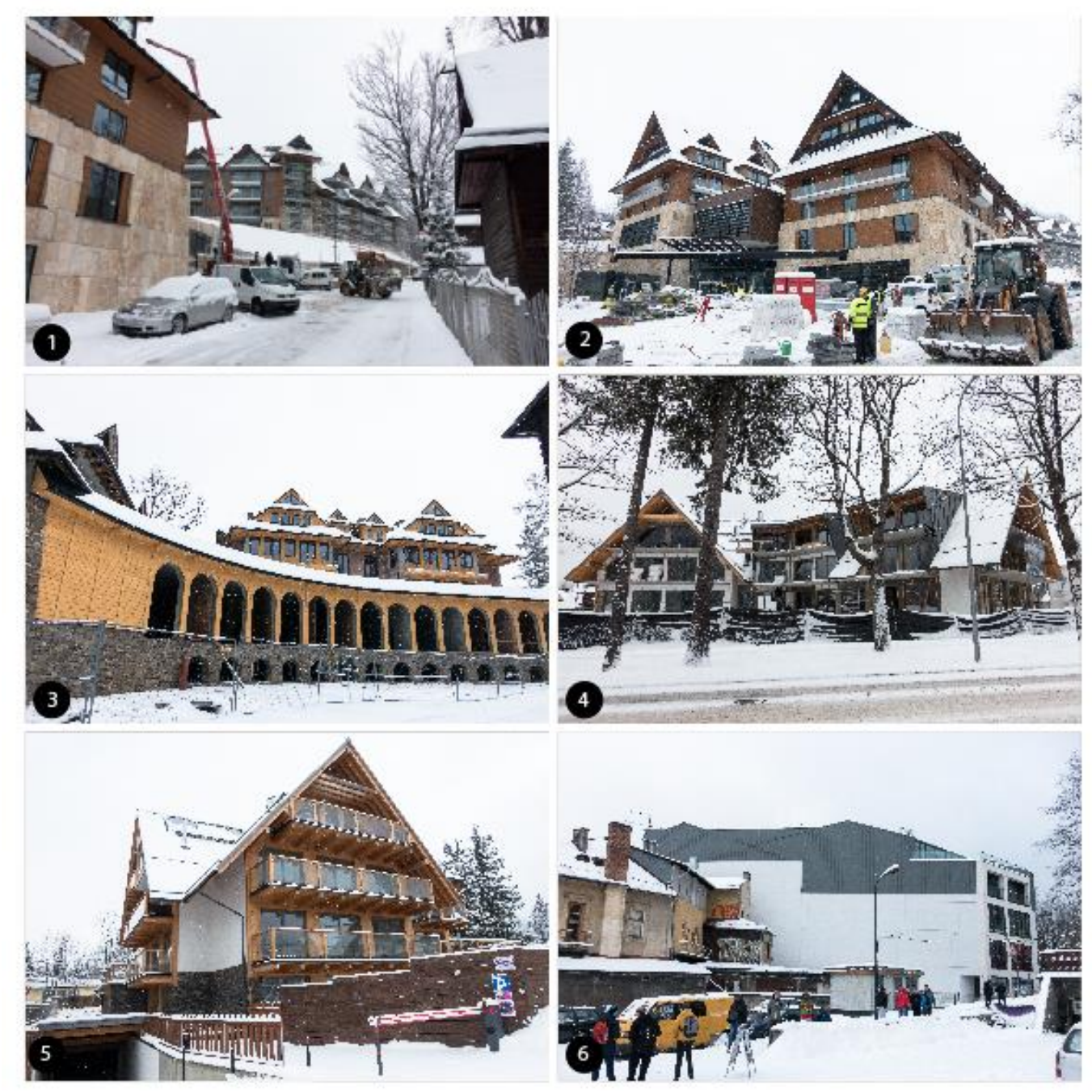

Figure 6. Current Developments in Zakopane (Photos 1-2. Radisson Hotel, Bulwary Stowackiego, Photo 3. Warszawianka, Jagielońska Street, Photos 4-5. Goszczyńskiego Street, Photo 6. Krupówki Street)

Source: Own Study. 


\section{Discussion}

Zakopane is losing its' original feel, and due to over-development, and wrong architectural choices, it has experienced severe criticism. Some initiatives work on the local issues - like for example the Krupówki Cultural Park ${ }^{16}$ (established in 2016) - that protects the image of the main street, ${ }^{17}$ and the social initiative "Zakopane without Smog" to clear the air in the town. There are many social consultations organised by the town's government, and unlike in the past, residents start protesting against the large - scale developments.

One of the ideas to help Zakopane with its' traffic problem was to create a big parking space in Nowy Targ or Szaflary based on the model of Park and Ride and connect both cities with a train. This concept created in the 80s' of XX century, unfortunately even with a currently well-functioning train system has not been established.

The other solution to battle the ongoing communication problem in Zakopane is the public transportation system. Currently, the city does not offer many routes, and the schedule is also rather rare. Also, the creation of the shuttle bus between the main touristic attractions around the city would hopefully encourage people not to use cars. ${ }^{18}$

The guidelines for the development of a larger scale architecture in Zakopane should be established as soon as possible and should focus on the following aspects:

1. The lots of the larger scale constructions should be under more strict control. The scale of the buildings should correspond to the existing architecture, rather than dominating it.

2. The architectural arrangement plan should draw upon the neighbourhood.

3. The possible changes in the transportation conditions of the lot should be analysed and considered before the building permit.

4. The neighbours of the large-scaled buildings should be surveyed to determine the potential building size.

5. The obligatory underground parking lot should be a mandatory element of the functional program for every large scaled building providing parking lots for guests, visitors and stuff.

6. The existence of arranging green space around every structure should be mandatory

7. The Highlander citations should be careful and adapted appropriately to the design.

16. Co to jest park kulturowy? Retrieved from: http://www.jaroslaw.pl/co-to-jest-parkkulturowy. [Accessed 15 May 2018]..

17. Moździerz and Marcinek, Rys Historyczny Rozwoju Przestrzennego i Architektonicznego, 2016.

18. B. Rzygocińska - Tyżuk, Fenomen Ulicy Głównej jako "Serca Miasta”. Wybrane Przykłady (Krakow, Poland: Czasopismo Techniczne Politechniki Krakowskiej, 2008). 
Vol. 6, No. $1 \quad$ Stachura \& Mantyka: Zakopane, Poland: The Critical Analysis of...

\section{Conclusions}

Zakopane is unique when compared to many other touristic towns and villages in Europe. It's urban and architectural quality based on vernacular culture makes it a highlight of Poland's heritage. Because of political and economic factors, a large-scale architecture appeared in the town and the area much later than in, e.g. the Swiss resorts. Today, with a better understanding of sustainability rules and the appreciation of heritage value, it seems to be easier to protect vernacular culture.

On the other hand, the danger for Zakopane comes from its extending popularity. The new expressways and good train connections with major Polish cities and airports will even intensify tourist visits in the nearest future. Social media and numerous promotion actions by organisers of events also encourage people to come for shorter and longer stays.

The situation presented above is part of global trends and dilemmas for the development of historic cities and areas, which are affected by contemporary highintensity buildings. Some of the new investments may be prestigious. On the other hand, prestigious projects can be considered as stimulators of spatial development, protection of cultural resources and brand support factors. ${ }^{19}$

A result of a snowball can be noticed in the real estate market - high demand for lodging in Zakopane and area affected at very high prices for rent and purchase. A significant number of Poles decided to invest savings in a property in Zakopane. This strategy generated a strong demand for holiday apartments and houses. In the present urban circumstances (limited number and relatively small plots in the centre), a large-scale architecture became an inevitable result of factors influencing the town's development.

Today, Zakopane is in real danger. The town is facing many problems that so far, have no solution. The ongoing process of city transition may provoke the loss of authenticity of Zakopane heritage architecture. The historical, cultural and natural importance of this place should be more strictly protected; therefore, architectural projects should follow very restrictive rules. The role of social participation must strengthen allowing local people co-decide on the future urban development and architecture quality.

To save the genius loci of the place, change in the development direction is a pressing matter. The town may also require a more in-depth study on the threat assessment and possible solutions to show the strategic approach to secure and well-balanced sustainable development.

Urgent actions must be taken to stop and prevent negative factors and phenomena.

The Master Plan is highly needed for Zakopane, and the new document, unlike the current one, must be developed and revised by the same team of urban designers in order to keep unified points. Also, as in the past, the works of social

19. P. Loftman and B. Nevin, "Prestige Projects and Urban Regeneration in the 1980s and 1990s: A Review of Benefits and Limitations," Planning Practice \& Research 10, no. 3-4 (1995): 299-316. 
initiatives (e.g. Towarzystwo Opieki nad Zabytkami) is highly needed in order to educate and protect the heritage of the place. Other forms of highly effective locals' engagement are social consults, where residents can voice their opinion and ideas to the local government.

Changes in tourism are required as well. Education could increase the knowledge about the region in order to prevent degradation of local culture. Zakopane should also start re-shaping its image, which would overall shift the target group of the visitors. The activities offered in the city should include the wider variety of cultural experiences instead of mass events.

\section{Bibliography}

Białas, W. "Budarka." In Zakopane Czterysta lat Dziejów I. Krakow, Poland: Krajowa Agencja Wydawnicza, 1991.

Co to jest Park Kulturowy? [What is a Cultural Park?] Retrieved from: http://www. jaroslaw.pl/co-to-jest-park-kulturowy. [Accessed 15 May 2018].

Długołęcka, L. and M. Pinkwart. Zakopane Przewodnik Historyczny [Zakopane, Historical Guide.] Warsaw, Poland: Wydawnictwo PPTK Kraj, 1989.

Eljasz, W. Ilustrowany przewodnik do Tatr, Pienin i Szczawnic [Illustrated Guide to the Tatra Mountains, Pieniny and Szczawnice.] Poznan, Poland: J. K. Żupański, 1970.

Jabłońska, T. Styl Zakopiański Stanistawa Witkiewicza [Zakopane Style of Stanislaw Witkiewicz.] Poland: Olszanica BOSZ Publisher, 2008.

Krzysztofiak-Kozakowska, S. Sztuka Młodej Polski [Art Nouveau Art in Poland.] Kraków, Poland: Ryszard Kluszczyński Publisher, 1999.

Loftman P. and B. Nevin B. "Prestige Projects and Urban Regeneration in the 1980s and 1990s: A Review of Benefits and Limitations." Planning Practice \& Research 10, no. 3-4 (1995): 299-316.

Mantyka, M. "Zanim Powstało Miasto" [Before the City was Founded.] In Zakopane 75 lat Praw Miejskich. Zakopane, Poland: Urząd Miasta Zakopane, 2008.

Mantyka M. and S. Momot. Zakopane i Tatry [Zakopane and the Tatra Mountains.] Zakopane, Poland: Wydawnictwo Krokus, 2003.

Matlakowski W. Budownictwo ludowe na Podhalu [Folk architecture in Podhale.] Akademia Umiejętności; Skład główny w Księgarni Spółki Wydawniczej Polskiej, 1892. https://www.dbc.wroc.pl/dlibra/publication/6618?tab=1.

Moździerz, Z. "Dom pod Jedlami Pawlikowskich" [House "Pod Jedlami" of the Pawlikowski Family.] In Wydawnictwo Muzeum Tatrzańskiego im. Dra Tytusa Chatubińskiego w Zakopanem No. 24. Zakopane, Poland, 2003.

. Geneza i Rozwój Stylu Zakopiańskiego [The Origin and Development of the Zakopane Style.] Zakopane, Poland: Wydawnictwo Tatrzańskie, 2003.

Moździerz, Z. and R. Marcinek. Rys Historyczny Rozwoju Przestrzennego $i$ Architektonicznego [Historical Drawing of Spatial Development and Architecture. The Krupówki Culture Park Area in Zakopane.] Zakopane - Kraków, Poland, 2016. https://bit.ly/2KRatMs.

Pallasmaa, J. "Tradition and Modernity: The Feasibility of Regional Architecture in PostModern Society." The Architectural Review 183 (1988): 28.

Rączka J. W. Walka o Polski Styl Narodowy w Architekturze [Fight for the Polish National Style in Architecture.] Krakow, Poland: Wydawnictwo Politechniki Krakowskiej, 2001.

Rzygocińska - Tyżuk, B. Fenomen Ulicy Gtównej jako "Serca Miasta". Wybrane Przyktady [The Phenomenon of the Main Street as "the Heart of the City." Selected 
Vol. 6, No. 1 Stachura \& Mantyka: Zakopane, Poland: The Critical Analysis of...

Examples.] Krakow, Poland: Czasopismo Techniczne Politechniki Krakowskiej, 2008.

Tarnowski, J. "Styl Alpejski w Środkowej Europie i Polska Kontrakcja wobec niego - Styl Zakopiański" [The Alpine-Style in Central Europe and Polish Contraction against it Zakopane Style.] Estetyka i Krytyka 2, no. 25 (2012): 232-246.

Żychoń, S. "Rozwój Przestrzenny i Budownictwo" [Spatial Development and Construction.] In Zakopane czterysta lat dziejów I. Krakow, Poland: Krajowa Agencja Wydawnicza, 1991. 